\title{
International Economic Convergence Applied to China
}

\author{
OLHA PROKOPENKO ${ }^{1}$, VIKTORIIA SHCHERBACHENKO ${ }^{2}$, GANNA MUZYCHENKO ${ }^{3}$, DING XIN \\ YURIY OSSIK ${ }^{5}$ \\ ${ }^{1}$ Department of Economics, COLLEGIUM MAZOVIA INNOVATIVE UNIVERSITY, POLAND. \\ E-mail: prokopenko.olha.w@gmail.com \\ ${ }^{2}$ Department of International Economic Relations, SUMY STATE UNIVERSITY, UKRAINE. \\ E-mail: v.shcherbachenko@macro.sumdu.edu.ua \\ ${ }^{3}$ Department of Political Sciences and Law, SOUTH UKRAINIAN NATIONAL PEDAGOGICAL UNIVERSITY NAMED \\ AFTER K. D. USHYNSKY, UKRAINE. E-mail: gannamuzychenko@gmail.com \\ ${ }^{4} U$ krainian Cultural and Scientific Information Center, HARBIN ENGINEERING UNIVERSITY, CHINA. \\ E-mail: winerdx@163.com \\ ${ }^{5}$ Institute of Economic and Legal Problems, Karaganda Economic University, KAZAKHSTAN. \\ E-mail: prokopenko.olha.w@gmail.com
}

\begin{abstract}
The objective of the article is to studied phenomenon of international economic convergence applied to China. The analysis methods, synthesis, economic and managerial comparativists, economic statistics, Hofstede method are used in this work.

Authors have conducted comparative analysis of production and consumption within economic totalitarianism. This symbiosis of socialism and capitalism lies based on a convergent socio-economic system, the theoretical foundations of which reside at the beginning of creation.

The changes in economic activity were tremendous at the end of the 20th and the beginning of the 21st century. It has been identified that the current world experience includes de-globalization, re-industrialization, new economics and management. The conducted research will be useful for trade policy development, international economic relations with investigated countries.

The authors carried out an analysis of the cultures of the studied countries using the Greet Hofstede method. The role of Confucianism as a religion and philosophy in the economic development of China is revealed. The Chinese governance model is investigated that consists of three elements: democracy, experimentation between local and central government, meritocracy.
\end{abstract}

Keywords: decentration; centration; culture; philosophy; management; economic convergence.

Clasificación JEL: E 71, F63, 053

Recibido: 2 de Noviembre de 2020

Aceptado: 8 de Enero de 2021 


\section{Introduction}

In the globalized financial sector, designed to be the "blood vessels of the economy," only $2.2 \%$ of money turnover is related to providing the functioning of production, and $98 \%$ are speculative (predatory) deals, behind which there is no real production of goods and services (Ossik, 2017). So, according to Baudrillard (2000), the world economy consists of the real economy and the giant virtual economy bubble. Baudrillard believed that the amount of capital was 45 times less than the volume of capital flow. It is the giant bubble of financial capital giving birth to multi-billion-dollar wealth. It is impossible to make it selling essential things. However, in the virtuality of financial transactions, it is possible at any time (Baudrillard, 2000).

The globalized financial sphere influences the state budgets and interests buys and overthrows governments, bankrupts individual countries (Funk, 2019). This total shadow government institution is progressively coming out of the shadow and lobbying its interests in states and supranational regions. Moreover, there is no alternative to it. Moreover, the lack of an alternative is totalitarianism. The political totalitarianism has a negative connotation. In any case, socialist production totalitarianism or capitalist consumer totalitarianism is the absence of choice (Trunev et al., 2009). In the first part of our article, the question will be about this absence of choice, not only in the financial sphere but also in the socio-economic functioning of national economies as a whole, in which most countries of the world turned out to be in the 21st century (Muzychenko \& Xin, 2018). The second part is devoted to national economies' functioning under the conditions of combining the antinomic socioeconomic system on China's example.

The objective of the article is to studied phenomenon of international economic convergence applied to China. The analysis methods, synthesis, economic and managerial comparativists, economic statistics and Hofstede method are used in this work.

\section{Literature review and theory development}

In this paper, we focus on the fact that both cultures do not give the right of choice, which means that they are totalitarian, although in different directions. We have compiled a table comparing various economic totalitarianism types - production and consumption (Table 1). Some descriptive data presented in work (Trunev et al., 2009), supplemented by our data, are used and interpreted.

A human's image in a consumer society's mythology is formed based on serving his own body. The feat of serving the body in different variations (sports, medical, etc.) seems to be the only worthy human existence goal. The semantic core of a feat as an individual act is consumption divided into several subtypes: time overcoming (expunging the signs of time), space consumption (tourism, "aggressive" kinds of sport), consumption of any kind of material objects and their virtual copies. The primary purpose of indicated types of serving is to achieve a state of everlasting obtaining the pleasures, i.e., the endless consumption of the attained abundance.

The consumer society is persistently sharing the phantom of material abundance in the face of the "golden billion" with the "non-gold" countries. The manifestation of this kind of empathy through trade and economic relations is specific. Let us consider some nuances of international assistance that the rich developed countries have provided to the poor and developing countries for decades, with a "burden" of democracy.

In contrast to the "overwhelming majority", such Asian countries as Japan, South Korea, Singapore, and China, named as newly industrialized countries in some sources, position themselves separately. Let compare these countries by Hofstede Framework (Fig.1). Geert Hofstede is an influential Dutch social psychologist who investigated the interconnection between national cultures and organizational cultures. He focused on a comparison of nations using statistical analysis. The goal of Hofstede's framework is to understand how the values underlie organizational behaviour. Key-value dimensions that analyse and interpret the behaviours, values, and attitudes of national culture are:

\section{Power distance.}


2. Individualism.

3. Masculinity.

4. Uncertainty avoidance.

5. Long-term orientation.

6 . Indulgence.

Table 1. Comparative analysis of production and consumption within economic totalitarianism

\begin{tabular}{|c|c|c|}
\hline Characteristic & Cult of production & Cult of consumption \\
\hline $\begin{array}{l}\text { The main semantic } \\
\text { concept }\end{array}$ & Serving the community and the state & Serving the body and emotions \\
\hline Periodization & $20-80$ s of the $X X^{\text {th }}$ century & $\begin{array}{l}\text { The end of the } X^{\text {th }} \text { - the beginning of the } X X I^{\text {st }} \\
\text { century }\end{array}$ \\
\hline $\begin{array}{l}\text { Management struc- } \\
\text { ture }\end{array}$ & Explicit hierarchy & Hidden hierarchy \\
\hline Concentration & Soviet culture & Western culture \\
\hline Source & State authority & $\begin{array}{l}\text { The power of TNCs and supranational finan- } \\
\text { cial structures }\end{array}$ \\
\hline $\begin{array}{l}\text { The focus of cultural } \\
\text { development }\end{array}$ & $\begin{array}{l}\text { To develop and move the industry for- } \\
\text { ward, expand production }\end{array}$ & $\begin{array}{l}\text { Increase per capita GDP and consumption } \\
\text { level }\end{array}$ \\
\hline Ideas & $\begin{array}{l}\text { The creative power of totalitarian power. } \\
\text { Production efficiency depends on the gov- } \\
\text { ernment's average citizen's trust and } \\
\text { readiness to become a conductor of the } \\
\text { specified creative power. }\end{array}$ & $\begin{array}{l}\text { Consumption is the activity in the field of sys- } \\
\text { tematic manipulation of symbols, signs (con- } \\
\text { sumption of emotions, virtual images, and } \\
\text { not only and not so much commodity-mate- } \\
\text { rial benefits) }\end{array}$ \\
\hline $\begin{array}{l}\text { Access to infor- } \\
\text { mation }\end{array}$ & $\begin{array}{l}\text { Free access is declared but not imple- } \\
\text { mented. }\end{array}$ & $\begin{array}{l}\text { Free access is declared and simulated, but the } \\
\text { information infrastructure's inhomogeneity } \\
\text { provides the asymmetry of access to infor- } \\
\text { mation. The asymmetry of information flows } \\
\text { by intensity and content in different direc- } \\
\text { tions }\end{array}$ \\
\hline $\begin{array}{l}\text { Significance, effi- } \\
\text { ciency }\end{array}$ & $\begin{array}{l}\text { Demonstration of production results at } \\
\text { National Economy Achievement Exhibi- } \\
\text { tion }\end{array}$ & $\begin{array}{l}\text { Demonstration of the abundance consumed: } \\
\text { garbage, waste, packaging }\end{array}$ \\
\hline Information images & $\begin{array}{l}\text { The world of creation after the preliminary } \\
\text { destruction }\end{array}$ & $\begin{array}{l}\text { The world of creation inside and gradual de- } \\
\text { struction outside, leading to disasters }\end{array}$ \\
\hline Methodology & Analytics and creativity & Service and technical support \\
\hline $\begin{array}{l}\text { Overcoming the mat- } \\
\text { ter }\end{array}$ & $\begin{array}{l}\text { Increasing the possibility of labor produc- } \\
\text { tivity, labor outcome }\end{array}$ & $\begin{array}{l}\text { Resistance to the established order. } \\
\text { Increasing the capacity of the body (first of all, } \\
\text { physical) in the consumption of products, ser- } \\
\text { vices, sex, the information in the formation of } \\
\text { a perfect body. }\end{array}$ \\
\hline $\begin{array}{l}\text { Interpreting the con- } \\
\text { cept of poverty }\end{array}$ & Spiritual & Material \\
\hline
\end{tabular}

Source: concluded according to (Wada, 2016) 
Figure 1. Country Comparison by Greet Hofstede Method

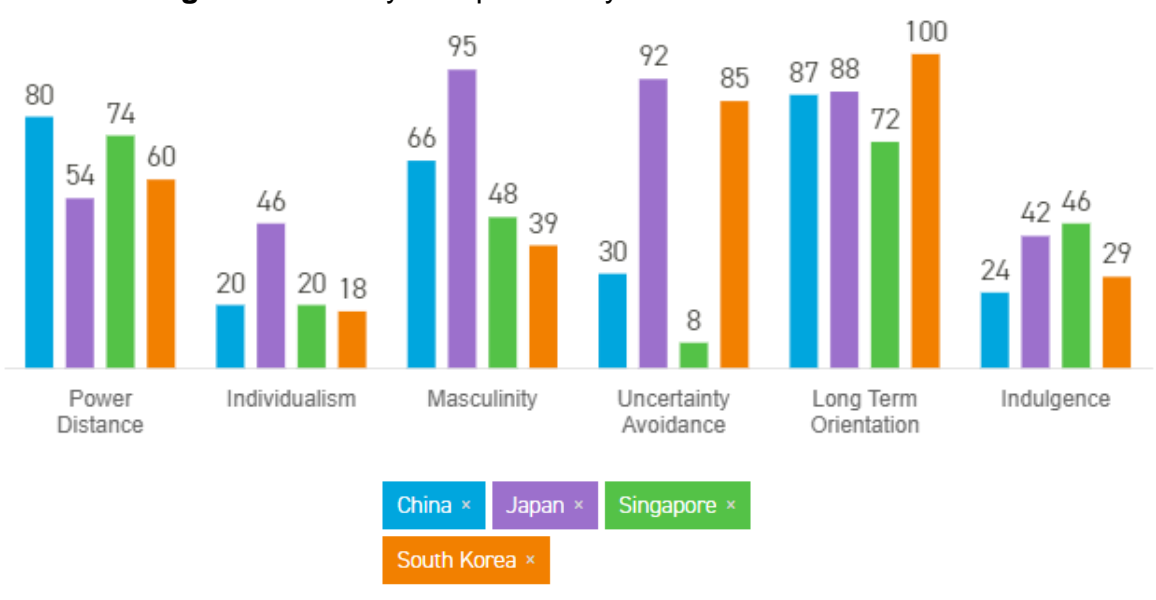

Source: created with Hofstede-Insights

The last decades have also shown that not all countries see their development in the unrestrained GDP growth per capita. Those who see, then they already feel captured by consumer totalitarianism. Not all countries accept and understand globalization as a panacea for the further successful functioning of the national economies in a single global mega economy.

Wealthy European countries are trying to escape from the crisis caused by the excess of democracy, especially from tomorrow's crisis connected with aging and degeneration of the population, unemployment because of future robotization, and pollution of the environment (Podgorna et al.,2020). After all, they moved their "dirty" production to the third world countries with more "soft" standards and regulatory requirements for its protection (Hostettle, 2013; Kerner, 2018; MontónSubías \& Hernando, 2018; Mamdani, 2016). So far, their effort to escape is not successful. Moreover, the Protestant culture that blesses same-sex marriages and almost communist equality of men and women in society and public production comes to a deadlock. Moreover, the refusal of the previously proclaimed socio-economic guidelines for at least the medium-term future is the sign of the crisis of the modern Western (in various forms imposed on the whole world) concept of economic globalization having no alternative. The realities of world experience are de-globalization, re-industrialization, new economics and management (Dzwigol et al., 2020; Prokopenko et al., 2019).

The extended literature review allowed to make the following theoretical proposition for future studies:

Proposition 1: In the sphere of globalization, the crisis was marked by the fact that it began to show tangible and significant failures among its consistent apologists, the developed countries.

Proposition 2: In the area of transition to the post-industrial society, an analogical reversal is observed. It is still a slow, but already noticeable turn from the dominance of financial bubbles producing nothing (except for deepening inequality in society), that oppress the economy, to real industrial production.

The changes in economic activity at the end of the 20th and the beginning of the 21st century are so radical and paradoxical that they require careful research and understanding. We will name only a few of them:

1. Departure from the model of rational behavior of economic subjects both as a whole and in conditions of awareness of eschatological economic activity. For the first time in history, at the beginning of 2002, a psychologist was awarded the Nobel Prize in Economics for proving the domination of emotional stimulators of economic behavior, and rational ones as supportive and controlling.

2. To a certain extent, neutralization of markets and activation of institutions in the sphere of activity of economic entities, monopolizing high-tech industries with the promotion of globalization.

3. Awareness of the situation under the pressure of irrefutable facts that a simulation economy is a more significant driving force for economic development than an innovative one. 
4. Establishment of the economy and management of the eastern type in the world economic space, which give a head start to Western economic thought and its practical implementation: in the period of the world economic crisis of 2007-2008 years, against the background of a negative increase of economic activity even in highly developed countries, the GDP of China, India and some other Asian countries increased to $5 \%$ or more per year.

5. The end of the self-isolation stage of theoretical economics and the awareness of the subordination of the canons of economic activity to cultural institutions and several related and non-related scientific fields: sociology, psychology, ethics, and even physics.

The idea of several modernization methods is also expressed in the theory of convergence (Osik, 2012). In the competition of two irreconcilable socio-economic systems, all means are reasonable. Therefore, from the very beginning, this theory acquired an ideological and political bias. Under globalization conditions, the general trends of scientific and technical and socio-economic progress cause closing-in, i.e., convergence, of the economies of an increasing number of countries while keeping their national peculiarities. Convergence in the economy is closing-in of the principles of public life's socio-economic arrangement by borrowing ideas, management forms, and technologies to improve the national economy's efficiency at the global level. Convergence is not only the result of developing the national economy (Bezglasnaya \& Grigoryieva, 2009).

Economic growth and development were the main factors for China's rise (Kleiner, 2017). Due to the ongoing reforms, thanks to a dynamic increase in GDP, a significant increase in the population's living standard, well-being, and "average subsistence" have been achieved. By 2015, the PRC turned into a superstate with its advanced technologies: the share of innovative products in GDP was about $30 \%$. The transformation of China, which in 1970 was one of the poorest countries, into the second pole of the world is one of the main trends in world development in the 21st century in the context of globalization (Babenko et al., 2020).

Figure 2. The innovative State of China

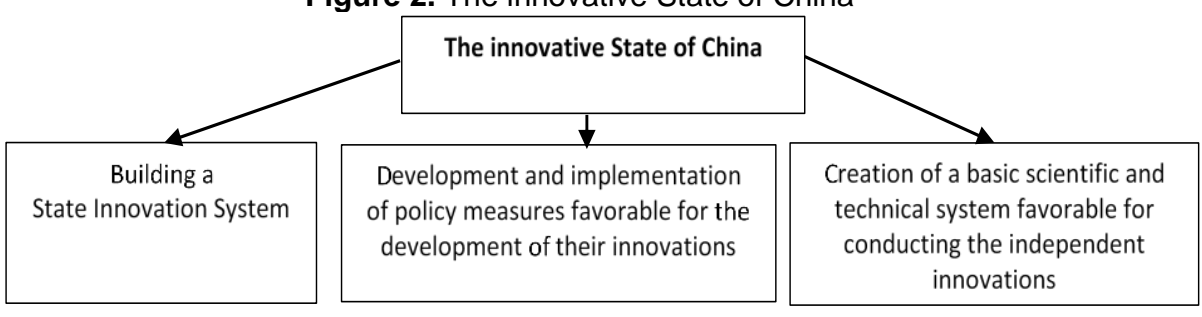

Source: created by authors

To solve building an innovative state, the republic's leadership identified many of the most critical issues in this area (fig. 2). Within the framework of this state task, the government of China identified the following goals:

1) building a technological innovation system using an organic combination of production, research, and academic structures based on manufacturing enterprises;

2) building a system of knowledge innovation through an organic synthesis between scientific and technical research structures and educational institutions;

3) creation of a union between the military and civilian sectors of production, the state defense innovation system functioning in the interests of both the defense and civilian industries;

4) formation of an innovation system that takes into account the regional specifics and advantages of individual Chinese regions;

5) creation of a service mediation system aimed at the society as a whole, united by the network space.

The concept of economic reform in the PRC, the Chinese paradigm of economic development were formed and evolved under the influence of theoretical ideas of management and academic community about the shortcomings of the old and desired new qualities of the emerging economic system 
of the socialist market economy, familiarity with the relevant experience of other countries and, to a greater extent, under the influence of practice, the response of the economy and society to specific innovations, as well as taking into account Confucian traditions.

The success of Confucian ideas in public administration was determined by the fact that Confucius was able to express the Chinese mentality's traditional features. Confucianism as a philosophy of management is increasingly viewed as a factor promoting the development of the economy, as the Chinese nation's principles embodied in this doctrine facilitated the stable, harmonious development of both the individual and the state. The principle of human behavior in China is the common welfare, the prosperity of the people and the state, but not personal vested interests. The ethical and political unity is ensured by fostering individual moral principles following the rules of behavior established in society. The reformers proceeded from the fact that the rules, adopted to establish order in the state, were not enough. Along with formal laws, a person's profound internal transformation is also required, to which Confucianism helps fundamentally (Babie \& Sarre, 2020; Hensold et al., 2020).

Confucian principles can be traced in the concept of building a harmonious society: for the ruler, "generosity" and the ability to appreciate the people are essential that presupposes granting the independence of a certain degree to ordinary people to satisfy their interests; the requirement of strict following public laws are combined with the simultaneous recognition of the possibility of privacy (Maksimov, 2011). Thus, the public and the personal do not contradict each other but are brought into a harmonious unity.

The Confucian theory of management allowed to overcome the most critical contradictions that threatened society's stability, for example, the contradictions between the rich and the poor, because the ruling elite was selected from all social strata, and the support of the majority of the population was provided. Also, one can note the absence of opposition between the intellectual class and the government due to the political orientation of education that was characteristic of other civilizations, especially Western ones. An educated person, a representative of the intellectual class, turned out to be included in the state system and directed his efforts towards its support and preservation, but not towards criticism and destruction. Thus, this system allowed to minimize the global contradiction between the individual and the public, and the inner thoughts and experiences of a person did not conflict with state interests. For Western civilization, the clash of the upper and lower strata, the intellectual class and the authorities, the individual, and the social ended in violent shocks. The official ideology of China is aimed at the ideal of the Confucian "golden mean", designed to bring together those ideas that, at first glance, seem to be incompatible. First of all, this tendency is manifested in the combination of various forms of ownership and various political principles.

China abandoned the thoughtless use of monetarist methods of transition to the market economy. The theory of the "socialist market economy" was developed based on the transition from the command-administrative, over-centralized to the mixed economy, the combination of two economic systems: the market and non-market (planned), and three main ideologies: Marxist, neoliberal, nationalistically utopian, as well as Confucianism, which was the philosophy of managing in China (Edelglass \& Garfield, 2011).

Chinese economic reforms are inextricably linked with innovative development strategy by raising their science and education and operational implementation of new technologies and products borrowed from abroad and adapted to national conditions. China institutionalizes the idea that science and technology are the first productive forces. The state is building up its potential in the field of education: universities are increasingly interacting not only with research organizations and centers but also with industrial enterprises. As a result, science is becoming a productive force. It corresponds to the ideas laid down at the beginning of China's socio-economic transformations, which called science and technology "the manufacturing force of primary importance" and the concept of an "innovative state".

China did not even have to free the socialist economy from the control of the state planning apparatus and the communist party, as J. Galbraith saw it to build an innovative economy of market 
socialism in the country. The economic development of China is a vivid example of the relevance and practical applicability of the theory of convergence in the modern world, in which globalization seems not to increase the mobility of economic resources and equalize the level of access to them, but to restructure the economic and political institutions that result in further polarization of national economies, the international division of labor and, ultimately, the standard of living of the population of different countries (Cherniavska et al., 2020; Lorincová, 2018).

Western scholars distinguish democracy and autocracy in the field of management. In modern concepts, a continuum of leadership behavior between democracy and autocracy is possible, but the field between them does not clearly define the intermediate stage. At best, there are several of them, and they do not have established fundamental differences.

The imperceptible symbiosis of democracy and autocracy in the West was found and called meritocracy by the Chinese. And not only its basic provisions and principles were formulated, but also they are successfully implemented in national socio-economic practice. The Chinese model of governance (Bell, 2017) consists of three elements: democracy below; experimentation between local and central government; meritocracy at the highest level (fig. 3).

Figure 3. The Chinese model of governance

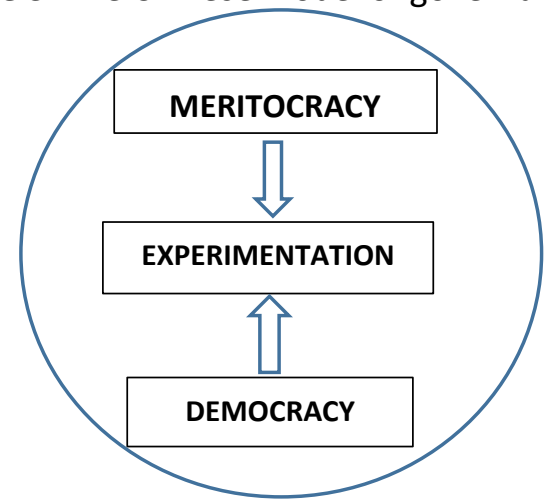

Source: created by authors based on (Bell, 2017)

The idea that the political and economic systems should try to select and promote leaders with outstanding abilities and virtues is central in China and the West's political theory and practice (Bigas et al., 2013). China embodies this idea with the help of meritocracy, and the West - with the help of democracy. In recent decades, China has fewer failures and more success. Maybe it happens because the ideal of the "Great Way" (da dao) is strictly observed, and it corresponds to the ideal of meritocracy, according to which "deserved and capable people should be appointed to leadership positions" (Huang, 2016).

The most challenging thing in a meritocracy (and in any form of government) is the provision of virtuous leaders. A leader with outstanding intellectual and social skills, but without proper virtues, is the worst type of leader, as he can develop the best way to implement immoral goals (A. Hitler's unique oratorical abilities). It is noteworthy that $\mathrm{D}$. Bell calls people who are devoid of conscience deviants. Any leadership theory that does not include ethics becomes flawed. D. Bell (2017) considers this obvious, but rightly complaints that very little (English) literature devoted to leadership focuses on ethics. In the post-Soviet space, the situation is similar. There are some exceptions of single publications located on the periphery of mainstream management (Ossik, 2017).

The paradigm of leadership-ministry cannot be applied in all organizations, situations, or development stages that they experience. It creates the most favorable conditions for modern social institutions' development, the basis for society's functioning. We find one of the first practical examples of the use of this paradigm in modern China. If the goal is to select leaders who strive to serve society, then the minimum condition will be to remove those who harm this society. Therefore, candidates with a criminal background, especially those accused of serious crimes, such as murder and rape, should be denied the right to hold any state positions (without mentioning the highest ones). In China, 
political leaders cannot hold political positions if their guilt of committing such crimes is proven. Moreover, it is widely believed that respect for their parents is necessary to develop respect for others and the development of morality outside the family. Therefore, it makes sense to eliminate candidates who have violated the basic norms of respect for their own family.

\section{Conclusions}

In recent decades the astonishing economic success of one and a half billion China and tiny Singapore, South Korea, China, and Japan is largely due to the lack of "centrism" in culture, art, science, and economic policy. While the post-Soviet developing countries are trying to reach one of the poles: democracy or autocracy, capitalism or socialism, a market or team economy, liberalism or protectionism, then they rush from one pole to another, the development of meritocracy in political and economic management has led to success not only China but also other eastern countries. Trying to look into the future, in the context of the outlined review, we note the following. The experience of socio-economic development of China suggests that answers to questions about the fruitful directions and rates of development of these processes in the future can be found using not just an interdisciplinary approach, but a historically inextricable connection between economics and culture, as well as a departure from centration and centrism. At the same time, one must allow sounding the infinitely rich harmony of the world according to the testament of Confucius - "in harmony with everyone, but not become similar to anyone".

\section{Acknowledgment}

The research was partly supported by the Sino-Ukrainian Cooperation Fund of Harbin Engineering University.

\section{References}

1. Babenko, V., Pravotorova, O., Yefremova, N., Popova, S., Kazanchuk, I., Honcharenko, V. (2020). The Innovation Development in China in the Context of Globalization. WSEAS Transactions on Business and Economics, 17, 523-531. https://doi.org/10.37394/23207.2020.17.51

2. Babie, P., \& Sarre, R. (2020). Religion matters: The contemporary relevance of religion. Religion Matters: The Contemporary Relevance of Religion, p. 1-343.

3. Baudrillard, Zh. (2000). Transparancy of evil. Translation into Russian: L. Lyubarskaya, Ye. Markovskaya. Moscow.

4. Bell, D. (2017). Chinese model. Political meritocracy and democracy. Our format, Kyiv, 312.

5. Bezglasnaya, E.A., \& Grigoryieva, A.V. (2009). Convergence of the economic development of national economies in the context of globalization. Retrieved from http://econf.rae.ru/article/6429

6. Bigas, Vidal, M., Bravo Farré, L., Fernández, A., \& Contepomi, G. (2013). China versus the west. Architectural expression, image and graphic thinking: Notes on a comparison, 21, 52-61.

7. Cherniavska, O.V., Liu, Y.-R., Cherniavska, O.D., Khan, I., \& Zham, O. (2020). Scaling up Chengyu's role in $\mathrm{Xi}$ Jinping's government policies concept: From specific Chinese national linguistic constructions up to markers and goals of the geo-economic development strategy. International Journal of Management, 11(5), 185-194.

8. Dzwigol, H., Dzwigol-Barosz, M., \& Kwilinski, A. (2020). Formation of Global Competitive Enterprise Environment Based on Industry 4.0 Concept. International Journal of Entrepreneurship, 24(1), 1-5.

9. Edelglass, W.A., \& Garfield, J.L. (2011). The Oxford Handbook of World Philosophy, 1-656.

10.Funk, A.S. (2019). The concept of crowdfunding in the west versus in China. Contributions to Management Science, 51-93.

11.Hensold, J., Kynes, J., Ohlmann, P., Rau, V., Schinagl, R.C., \& Taleb, A. (2020). Religion in Motion: Rethinking Religion. Knowledge and Discourse in a Globalizing World, 1-255. 
12. Hofstede Insights. Retrieved from https://www.hofstede-insights.com/country-comparison/china,japan,singapore,south-korea/

13. Hostettler, N. (2013). Dialectic and explaining eurocentrism the dialectics of the europic problematic of modernity. Journal of Critical Realism, 12(1), 45-71.

14.Huang, P.C.C. (2016). Our Sense of Problem: Rethinking China Studies in the United States. Modern China. 42(2), 115-161.

15.Kerner, I. (2018). Beyond Eurocentrism: Trajectories towards a renewed political and social theory. Philosophy and Social Criticism, 44(5), 550-570.

16.Kleiner G.B. (2017). Institutional factors of long-term economic growth. Economic science of modern Russia, 1, 5-20.

17.Lorincová, S. (2018). Human resource and corporate culture: Gender-based differences in the assessment. Central European Journal of Labour Law and Personnel Management, 1 (1), pp. 28 - 45. http://doi.org/10.33382/cejllpm.2018.01.03

18.Maksimov G. (2011). Confucianism as a religion. Retrieved from http://www.bogoslov.ru/text/1875775.html

19. Mamdani, M. (2016). Beyond eurocentrism and anarchy: Memories of international order and institutions. Comparative Studies of South Asia, Africa and the Middle East, 36, 174-177.

20.Montón-Subías, S., \& Hernando, A. (2018). Modern Colonialism, Eurocentrism and Historical Archaeology: Some Engendered Thoughts. European Journal of Archaeology, 21(3), 455-471.

21.Muzychenko, G., \& Xin, D. (2018). Political and legal factors of Ukrainian-Chinese relations of strategic partnership. Socio-economic research bulletin, 4(68), 234-241.

22.Osik, Yu.I. (2012). Proto-renaissance of the theory of convergence in modern economic development: the experience of China. Social modernization of Kazakhstan: prerequisites, achievements and ways of development. Materials of International scientific and practical conference, 25th of October 2012, 90-95.

23.Osik, Yu.I. (2017). Chinese civilization from the point of vision of western culture and its embodiment in the economy. Bulletin of ONEU, 108-130. Retrieved from http://n-visnik.oneu.edu.ua/collections/2017/251/pdf/108-130.pdf

24.Podgorna, I., Babenko, V., Honcharenko, N., Sáez-Fernández, F. J., Fernández, J. A. S., \& Yakubovskiy, S. (2020). Modelling and Analysis of Socio-Economic Development of the European Union Countries through DP2 Method. WSEAS Transactions on Business and Economics, Volume 17, 2020, Art. \#44, pp. 454-466. doi: https://doi.org/10.37394/23207.2020.17.44

25.Prokopenko, O., Omelyanenko, V., Ponomarenko, T., \& Olshanska, O. (2019). Innovation networks effects simulation models. Periodicals of Engineering and Natural Sciences, 7(2), 752-762. DOI: 10.21533/pen.v7i2.574

26.Trunev S.I., \& Palkova V.C. (2009). Homo sovieticus \& Homo consumens: feats of production and consumption (philosophical analysis). Bulletin of Chelyabinsk State University, 33(171). Philosophy. Sociology. Culturology. Edition, 14, 35-40.

27.Wada, H. (2016). Normative hierarchy in informal economic institutions: Docile China versus the assertive west. International Journal of China Studies, 7(2), 175-195. 